\title{
THE EMERGENCE OF MACROPRUDENTIAL BANK REGULATION: A REVIEW*
}

\author{
Katalin MÉRŐ \\ (Received: 17 May 2016; revision received: 22 August 2016; \\ accepted: 18 September 2016)
}

\begin{abstract}
Although the macroprudential regulation only became a central topic of bank regulation after 2008, recognising and analysing risk, what now we call macroprudential, has formed part of the thinking about banking risk for a long time. A real turn of events was caused by the Global Financial Crisis. Since then, as a consequence of the huge taxpayers' burden and the mutual reinforcing effect of sovereign and banking crises, the main course of bank regulation has become the elaboration and implementation of regulation with a macroprudential perspective. This article reviews the history of the international evolution of macroprudential regulation from the perspective of both the regulation's motivations and its conceptual and practical developments. Its main focus is the development of the ideas of a macroprudential perspective on prudential policy and the way these ideas eventually led to concrete experiences with macroprudential regulatory tools. As a conclusion, the author raises the question of whether the financial system has become more stable by implementing the current form of macroprudential regulation.
\end{abstract}

Keywords: macroprudential, bank regulation, banking crisis, Basel III, European Union, Global Financial Crisis

JEL classification indices: G21, G28

* The author would like to thank Júlia Király, Judit Neményi and Dóra Piroska for their helpful comments on an earlier version of the paper.

Katalin Mérö, Associate Professor at the Department of Finance, Budapest Business School. E-mail: mero.katalin@uni-bge.hu 


\section{INTRODUCTION}

As a consequence of the Global Financial Crisis (GFC), a significant shift in perspectives in the area of bank regulation can be observed. Besides the earlier regulation that was microprudential, i.e. it had in mind the stability of individual institutions, the defining characteristic of the regulatory changes today is the emergence of a macroprudential perspective, i.e. the formation of a bank regulation that additionally has in mind the risks building up in the financial system as a whole.

The risks called macroprudential in today's terminology have been known for a long time: the build-up process of cyclical financial risks and the subsequent financial crises are quite well documented, going back several hundred years. Even so, until the GFC, the evolution of bank regulation was dominated by the expectation to protect against the microprudential risks that had been identified and measured increasingly more precisely. The motivation for establishing the Basel Committee on Banking Supervision in 1975 was the creation of a consistent bank regulation that is equally valid for everyone, is competitively neutral on the international level, and acts against the banks' identically measured and handled individual risks. The international financial institutions and several academics realised the existence and significance of macroprudential risks only as a consequence of the big financial crises in the late 1990s, the Asian and Russian crisis, and the collapse of the Long-Term Capital Management (LTCM $)^{1}$. However, the macroprudential perspective did not gain ground in bank regulation at the time, and the central concern of regulation continued to be the development of rules focusing on individual institutional risks. The so-called Basel II bank regulation system - published in 1999 in its first version and applied from 2007 - built on the banks' best practices in risk management to an important extent. Thus, it inherently had a microprudential perspective. The macroprudential turn was brought by the GFC. The shock caused by the GFC made all stakeholders realise that the main causes of financial crises were macroprudential risks. Following the GFC, new institutions supporting macroprudential regulation and supervision were created. The Basel III regulation package as well as the European and national regulations based on it supple-

1 Long-Term Capital Management (LTCM) was a hedge fund founded in 1993 and hallmarked by two American economists, Robert Merton and Myron Scholes, who received the Nobel Prize for their results in the area of derivatives pricing. LTCM was looking for arbitrage opportunities using a model developed for this purpose, and they made a huge profit in the first years of operation. By 1998, the time of the Russian crisis, the models applied by LTCM have become general professional practice, and that has amplified the effects of the crisis to a great extent (Dunbar 2000). 
mented the regulatory system with numerous macroprudential elements. Macroprudential regulation was thought to become a "wonder weapon" that would help to avoid future financial crises.

This paper reviews the history of the evolution of macroprudential regulation from the perspective of both the regulation's motivations and its conceptual and practical development on an international and European level. Its focus is the development of the ideas of macroprudential perspective on prudential policy and the way these ideas eventually led to concrete experiences with macroprudential regulatory tools. Its structure is as follows: Section 2 reviews the history of identifying macroprudential risks and appearance of the macroprudential perspective. Section 3 presents the macroprudential turn that occurred as a consequence of the GFC; the structure of the institutions established for supporting macroprudential regulation and the newly created macroprudential regulatory system. Section 4 concludes and raises the question of whether the banking system has become more stable after the macroprudential turn.

\section{THE APPEARANCE OF THE MACROPRUDENTIAL PERSPECTIVE BEFORE THE GFC}

Although macroprudential risks and the macroprudential bank regulation came into the centre of attention of both academics and practical experts in bank regulatory policies as a consequence of the GFC, we can hardly claim that the reason for this increased attention was the novelty of the risks.

\subsection{Early identifications of macroprudential risks}

Well before the GFC, it was possible to identify the macroprudential risks as the reason of numerous systemic financial and banking crises. Analysing the causes of the Great Depression of 1929-1933, Irving Fisher (1933) already considered the build-up of systemic risks, although without giving it a specific name. However, the cyclical nature of lending (or, to use the current expression, procyclicality) formed an integral part of his reasoning. According to historian Charles Kindleberger, financial crises unfolded roughly every 10 years in the last 400 years (Kindleberger 1993: 264). Kindleberger elaborated on the theories of Fisher (1933) and Hyman Minsky (1986). He regarded the financial crises as bubblebased crisis, in which excessive credit expansion played a big role. In the two big and famous financial crises of the early $18^{\text {th }}$ century documented by him, the South Sea Bubble in England and the Mississippi Bubble in France, the creation 
and bursting of the bubble, based on share prices and financed by the bank, had an equally big role (Kindleberger 2001). They emerged on the systemic level and affected the financial system and the economy of the entire country, i.e. they conformed to the currently used notion of macroprudential risks.

After the liberalisation of the financial markets in the 1970s and 1980s, the international contagion of financial and banking crises gave a new impetus to the analysis of systemic crises. As a result of the Latin American, Scandinavian, and Central and Eastern European banking crises in the earlier 1990s, especially following the so-called Tequila Crisis in Mexico in 1994-1995, several important studies covered the definition of banking crises and the identification of their causes, with a particular focus on the causes leading to systemic crises. At the same time, academics and international financial institutions started to build the databases of the banking crises' occurrences, during which they took into account systemic banking crises, applying various definitions (see for example: Lindgren et al. 1996; Caprio - Kinglebiel 1996). However, despite the emergence of macroprudential approaches to financial stability, there were no signs of recommendations to move towards developing and integrating macroprudential regulatory tools in bank regulation.

The appearance of the macroprudential perspective is shown by the fact that the Bank of England, first among the central banks, published its Financial Stability Report in 1996 (Bank of England 1996), focusing on the banking and financial system's vulnerabilities. However, the publication of stability reports by central banks only became an internationally standard practice in the early 2000 s, following the crises at the end of the 1990s.

Clement (2011) documents the first appearances of the term "macroprudential". The expression initially appeared exclusively in internal working documents of central bankers, particularly of the Bank for International Settlements (BIS) and the Bank of England at the end of the 1970s. Clement links the first public appearance of the term to the BIS report about international banking innovations in 1986. The usage of the expression was sporadic until the end of the 1990s.

\subsection{Evolution of the macroprudential perspective: the period between the end of the 1990s and the GFC}

The Asian crisis in 1997, then the Russian crisis in 1998, and especially the collapse of LTCM that was closely linked to the latter, fundamentally changed the thinking on the banking crises. The interconnectedness of financial markets and the contagion effect as a consequence of it, the prevalence of herd behaviour, the uniform risk management systems, and particularly the application of models and 
limits dictating identical behavioural rules as the root cause of the systemic banking crises became an important part of common professional thinking. Simultaneously, there was a change in the terminology: besides "systemic risks", the use of the expression "macroprudential risks" became increasingly more frequent, and regarding bank regulation and supervision, the concept of macroprudential regulation focusing on systemic risks appeared as a counterpoint to the so-called microprudential regulation focusing on individual banks (Clement 2011: 63-65).

The speech by Andrew Crockett (2000), the then General Manager of the BIS, delivered in September 2000 at the $\mathrm{XI}^{\text {th }}$ International Conference of Banking Supervisors was considered a milestone. In this speech, he distinguished between the macro- and microprudential dimensions of financial stability based on their objectives and the principles of their mechanism of action, underscoring that this differentiation did not necessarily mean that the two types of dimensions should use different regulatory and supervisory tools. He defined the macroprudential objective as decreasing the social costs of a financial crisis, and the microprudential objective as decreasing the probability of the bankruptcy of individual institutions. In a macroprudential dimension, the principle of the mechanism of action is determined by the collective reactions of individuals and institutions, i.e. it should be considered endogenous. In a microprudential dimension, the risks are external for the financial institutions and the reactions are individual, i.e. exogenous. In his speech, Crockett noted that it would be justified to impose higher prudential requirements on the largest institutions with an importance from a systemic risk perspective and that preparations for worse times should be made in the periods of economic upturn, building up additional capacities for protection. This means that the prudential requirements, which were calibrated with a microprudential perspective in the same way for all institutions and were sized independently of the characteristics of the cycle, were not appropriate because they do not handle macroprudential risks.

Less than a month later, BIS organised the annual conference of central bank economists, "Marrying the macro- and microprudential dimensions of financial stability" (BIS 2001). The background paper for the conference was prepared by the BIS economists (Borio et al. 2001), and they focused on the problem of the build-up of macroprudential risks in time, namely on the procyclicality of financial intermediation, which means that financial institutions do not take into consideration to a sufficient extent the risks related to the changes of economic cycles: in good times they underestimate, and in bad times they overestimate them. The BIS experts argued that if the banks accumulated extra provisions and capital in the periods of economic upturn that would greatly promote financial stability. They considered four policy options for the actual implementation: 
(a) promoting the market participants to better understand the real nature and the build-up in time of the risks;

(b) empowering the supervisory authorities with discretional instruments in order to decrease the procyclicality (in the form of increasing the capital and/or provisions);

(c) imposing mandatory regulatory, supervisory, and accounting rules, defined as a function of an economic variable; and

(d) using the monetary policy toolset.

After assessing the advantages and disadvantages, they found that the most effective solution would be the introduction of mandatory prudential rules, primarily in the form of provisioning requirements. Thus, we can say that this paper already contained the regulatory ideas that have since become integral parts of the objective and instruments of bank regulation much later, after the GFC, as part of Basel III.

A study by Borio (2003), the then Chief Economist at the BIS, gave further clarifications. It contained the full range of the concepts and targets used today. On the one hand, it distinguished between the two dimensions of macroprudential risks, the cross-sectional and the time dimension, where the time dimension represents the procyclicality of risks and the cross-sectional dimension represents the risk concentrations existing at a given point in time (either the same risk exposure at several institutions or due to the large size of individual institutions). On the other hand, it also defined the micro- and macroprudential approach to bank regulation. Table 1 containing the comparison is regarded as the starting point by numerous analyses related to this topic and it appears in later BIS materials and other research papers as well (BIS 2008; Maes 2010; Borio 2011; Damodoran Lee 2014; etc.).

Table 1. The macro- and microprudential perspectives compared

\begin{tabular}{l|l|l}
\hline & Macroprudential & Microprudential \\
\hline Proximate objective & $\begin{array}{l}\text { Limit financial system-wide } \\
\text { distress }\end{array}$ & $\begin{array}{l}\text { Limit distress of individual } \\
\text { institutions }\end{array}$ \\
\hline Ultimate objective & Avoid output (GDP) costs & $\begin{array}{l}\text { Consumer (Investor/Depositor) } \\
\text { protection }\end{array}$ \\
\hline Model of risk & (in part) Endogenous & Exogenous \\
\hline $\begin{array}{l}\text { Correlations and common } \\
\text { exposures across institutions }\end{array}$ & Important & Irrelevant \\
\hline $\begin{array}{l}\text { Calibration of prudential } \\
\text { controls }\end{array}$ & $\begin{array}{l}\text { In terms of system-wide } \\
\text { distress; Top-Down }\end{array}$ & $\begin{array}{l}\text { In terms of risks of individual } \\
\text { institutions; Bottom-Up }\end{array}$ \\
\hline
\end{tabular}

Source: Borio (2003: 2). 
In accordance with the definitions used earlier by Crockett (2000), Borio (2003) distinguished between the macro- and microprudential perspectives not based on the types of regulatory tools, but on the regulatory objectives as well as the properties of the methods used for measuring and controlling risks. Accordingly, the same regulatory tool may be applicable for controlling either the micro- or the macroprudential risks.

The interesting part of the conceptual and analytic work performed at the BIS presented above is that the approach and the results were not included in the most important ongoing project of the Basel Committee on Banking Supervision: the Basel II capital rules. The Basel Committee on Banking Supervision (BCBS) operating next to the BIS published the first version of the Basel II capital rules in June 1999. The first version, intended to be final, was published in June 2004, after a long consultation period. It had a dominantly microprudential perspective because the perspective change compared to Basel I was that it built on the banks' best practices in risk awareness and risk management. Instead of the earlier regulation that was valid for everyone and had to be applied mechanically, Basel II introduced a three-pillar regulation. The first pillar, which determines the minimum capital requirement, makes it possible for the banks having higher risk awareness and better risk management systems to apply capital calculation rules that build more strongly on their own risk management practices, which is inherently microprudential. In the framework of the second pillar, the supervisory review process, the supervisory authority checks the banks' adequacy of internal capital calculation, that is the adequacy of capital allocation from a microprudential perspective. Under the third pillar, banks have to disclose information related to their risk profile, risk management, and the corresponding capital requirement, that is in a microprudential perspective.

The probable reason for this duality is that Basel II has been worked out not due to the crises in the later 1990s, but owing to the shortcomings of the earlier regulation. Even so, two not particularly powerful signs of the macroprudential perspective can be found in the internal rating-based methods of the first pillar. These are the "downturn LGD" and the "through the cycle PD", as supplements to the yearly perspective of the PD and LGD. ${ }^{2}$ However, these elements are not dominant parts of the regulation, they are present in Basel II more as "good wishes" rather than strong anticyclical elements due to their low level of elaboration (the lack of related calibration principles and standards). Beyond that, the requirement to perform a stress test does show up in multiple places among the

The PD (Probability of Default) and the LGD (Loss Given Default) are the parameters of the model, which determine the regulatory capital requirement under the internal rating based approach (IRB) of Basel II's first pillar. 
second pillar provisions, but the calibration is essentially microprudential, in accordance with the general perspective of the regulation.

In this light, it is not surprising that Basel II was heavily criticised during the consultation period, even before its introduction, because it supported the procyclical behaviour of the banks given its essentially microprudential perspective. Altman - Saunders (2001) drew the attention to the retroactive perspective of the ratings to be used for determining the capital requirement, in case of both internal and external ratings. The researchers of the Financial Markets Group at the London School of Economics (LSE) criticised the planned regulation for the complete absence of a macroprudential perspective (Danielson et al. 2001). They pointed out that the models used by banks that will become accepted in the regulation through Basel II do not take into consideration the endogenous nature of risks, and that capital requirement based on ratings considerably amplifies the procyclicality of the regulation.

Besides the BIS economists, the IMF also made many efforts in this period for spreading the macroprudential perspective. As a reaction to the Asian crisis, the finance ministers and governors of central banks of 22 developed countries with an internationally active financial system met in Washington in April 1998 and decided to set up several working groups with the goal of elaborating recommendations for stabilising the international financial system. One of these examined the possible methods to strengthen the national financial systems. One of this working group's recommendations was that the IMF should include the stability analysis of national financial systems in its regular country assessments with a much greater emphasis than earlier, also integrating the World Bank's professional expertise (Working Group on Strengthening the Financial Systems 1998). In accordance with the recommendation, the IMF launched the Financial Sector Assessment Program (FSAP), with the involvement of the World Bank, in May 1999, first as a pilot program, and later as a continuous and regular activity. From 2001, they started to publish regularly their country reports based on the FSAPs. In order to substantiate and unify the FSAP methodology, the IMF elaborated a system of macroprudential indicators (MPIs) (IMF 2000). The two large groups of the indicators defined in the MPI framework consisted of the indicators based on macro-statistics related to the financial sector and the aggregated microprudential indicators for the entire financial sector. With regard to the interpretation of the indicators, the paper repeatedly drew attention to the importance of stress tests built on possible negative macroeconomic scenarios.

As a result of the continuous analysis and development of the MPIs, the IMF published the system of Financial Stability Indicators (FSI) in 2002 (IMF 2002). 
The system consisted of a standard and comparable, so-called core set ${ }^{3}$ and a not completely standard, so-called encouraged (or additional) set ${ }^{4}$ of indicators. Since then the indicators have been regularly analysed by the IMF as part of the country assessments and the FSAP.

During this period, the appreciation of the responsibility for financial stability significantly grew in increasingly more central banks, as an influence of the international financial institutions and the leading central bank practices. Central banks, one after the other, began to publish their analysis and assessment related to financial stability.

In addition to the publications presented above, the strengthening of the macroprudential perspective of international financial organisations is reflected also by the creation of the Financial Stability Forum (FSF) in 1999. The FSF was a consultation forum operating next to the BIS, consisting of the G7 finance ministers and the governors of central banks.

Besides the materials of BIS, IMF, and the central banks, several academic studies were published that emphasised the macroprudential nature of risk. A part of these pointed out the interconnectedness of the financial market participants and analysed the contagion risk (Allen - Gale 2000; Rochet - Tirole 1996). The exogenous or endogenous nature of risks too were increasingly accentuated and there have been arguments supporting that the latter may be more threatening, causing greater damage in terms of the financial system's stability. Danielsson Shin (2003) illustrated this point using the case of trading strategies on the money and capital markets. When traders use the same risk management models, that represent the best practice of the industry, their decisions become harmonised, that is, the models dictate the same behavioural pattern to everyone. When market prices are falling, it affects the behaviour of traders. If the strategies applied by market players are similar, then their reactions will be similar, i.e. harmonised. The harmonised behaviour has a retroactive effect on market prices (e.g. in the form of closing positions en masse), resulting in a further price decrease. This can create a vicious circle that goes from the one-time price fall to the collapse of the market. Thus, the risk on the road to the collapse is generated and amplified within the system.

Despite all the intellectual efforts described above, nothing of this filtered down to the practice of bank regulation and supervision. Although the strength-

3 The core set of indicators contained 15 aggregated microprudential indicators by the following criteria: capital adequacy, asset quality, earnings and profitability, liquidity, and sensitivity to market risks. The five groups of indicators are built according to the quantifiable components of the so-called CAMELS method used by the FED for supervisory purposes.

4 The 26 additional indicators contained a mix of macroeconomic, aggregated banking system data, as well as aggregated data related to other financial institutions. 
Table 2. Development of macroprudential ideas and regulatory tools, from the late 1990s to the GFC

\begin{tabular}{l|c}
\hline Ideas & \multicolumn{1}{|c}{ Regulatory tools } \\
\hline $\begin{array}{l}\text { September 2000: speech of A. Crockett distinguished } \\
\text { the macro- and microprudential dimensions of financial } \\
\text { stability }\end{array}$ & No \\
\hline $\begin{array}{l}\text { October 2000: BIS conference "Marrying the macro- } \\
\text { and microprudential dimensions of financial stability" }\end{array}$ & $\begin{array}{l}\text { The idea of macroprudential regulation } \\
\text { articulated }\end{array}$ \\
\hline $\begin{array}{l}\text { IMF and World Bank launch the Financial Sector } \\
\text { Assessment Program (FSAP) from 1999; and work } \\
\text { out the underlying methodology: Macroprudential }\end{array}$ & No \\
$\begin{array}{l}\text { Indicators (MPI) } \\
\text { Borio (2003) theoretical foundation of macro- and } \\
\text { microprudential concepts }\end{array}$ & No \\
\hline $\begin{array}{l}\text { Several papers on macroprudential risks within the } \\
\text { whole period }\end{array}$ & \multicolumn{1}{c}{ No } \\
\hline $\begin{array}{l}\text { Extensive critiques of Basel II because of its } \\
\text { microprudential perspective }\end{array}$ & $\begin{array}{l}\text { No: Basel II regulatory reform } \\
\text { represents almost solely } \\
\text { microprudential approach } \\
\text { (first draft: 1999; final draft: 2004) }\end{array}$ \\
\hline
\end{tabular}

ening of the macroprudential perspective can be tied to specific financial crises, the consequences stayed on a conceptual level. And in practice, the direction of the evolution was marked by the development of the new regulatory system, the Basel II rules, based dominantly on the microprudential perspective, i.e. the banks' best practices in risk management. Table 2 summarises the development of macroprudential ideas and regulatory tools during this period.

\section{THE BANK REGULATION'S RESPONSE TO THE GFC: THE MACROPRUDENTIAL TURN}

The GFC has fundamentally changed the attitude of politicians and regulators towards macroprudential risks. As Claudio Borio wrote, macroprudence evolved from a concept used in a small circle into a key concept, from a concept of exclusively theoretical significance into a part of daily life, the most important direction of the bank regulation and supervision's evolution. Or, as he pointed out paraphrasing Milton Friedman, "We are all macroprudentialists now" (Borio 2011: 2). The widespread usage of the expression "macroprudential" is a consequence of the GFC as well (Galati - Moessner 2011).

As we have seen in Section 2, the macroprudential perspective as well as the potential toolset of the macroprudential regulation were well-known concepts, but only of a theoretical significance until 2008. As an effect of the GFC, implemen- 
tation of a bank regulation based on the macroprudential perspective appeared increasingly more often as a generally accepted requirement. Books, articles, and studies about clarifying the definition of the regulation with a macroprudential perspective, or some of its special individual elements, and about the possible methods of applying the macroprudential regulation appeared one after the other, in much higher numbers than before (Galati - Moessner 2011; Kálmán 2015).

Besides the economists and the regulatory authorities, the macroprudential perspective became part of the palette of interests of the political economy, marking a turn in changing the regulation's conceptual framework. Baker (2013) pointed out that before the GFC, bank regulation was built essentially on the assumption of efficient financial markets and the microprudential regulation based on it, while after the crisis, faith in market efficiency wavered and the need for a much more active state and state regulation that would intervene to prevent a crisis became essential. The growing awareness of the need for active state intervention and its legitimacy brought a turn of perspective in bank regulation (Mérő - Piroska 2013).

As an effect of the turn, efforts to support the establishment and implementation of national macroprudential policies have strengthened on international level. The volume and significance of macroprudential tools applied by the central banks and financial supervisory authorities of individual states have also increased considerably. Additionally, the general implementation of macroprudential regulation has become one of the main objectives in the renewal of the international bank regulation, the Basel III regulatory system.

\subsection{Evolution of the institutional framework for macroprudential regulation and supervision}

As part of the macroprudential turn, the system of institutions supporting the implementation of the macroprudential perspective has been established. The responsibility to establish, coordinate, and implement macroprudential policies has been assigned as follows: the Financial Stability Board (FSB) on a global level, the European Systemic Risk Board (ESRB) on a European level, the designated national authorities (usually the central banks) and, although to a lesser extent, the competent national supervisory authorities on national levels. ${ }^{5}$

5 The concept of national "designated authorities" entrusted with the conduct of macroprudential policy, different from the "competent authorities" responsible for banking supervision, was based on the Recommendation of the ESRB (ESRB/2011/3) on the macroprudential mandate of national authorities. 
The first quick reaction of the international regulatory community to the GFC was to establish the FSB on the basis of the FSF in April 2009. The international community acknowledged with this step that the FSF operating since 1999 was able to fulfil its objective of supporting financial stability to a quite limited extent only. This was partly due to its coverage limited to the G7 and partly to its weak mandate, exclusively for consultations (Helleiner 2010). The G20s and four other countries operating as important financial centres (Singapore, Hong Kong, Spain, and Switzerland) became members of the FSB. As a consequence, in principle, if the FSB agreed on a particular financial stability policy, those rules could be introduced in a group of countries covering a much larger part of the international financial markets. Besides the member states, four international institutions (BIS, IMF, World Bank, OECD) as well as the six international standard-setting bodies that are the most important in terms of the financial system, the BCBS, the International Organization of Securities Commissions (IOSCO), and the International Accounting Standards Board (IASB) among them, became also members of the FSB.

The FSB performs its coordination and monitoring task along four main reforms laid down by the G20s and defined as priorities. The priorities cover the activities performed at international standard-setting bodies, primarily at BCBS and IOSCO, which are considered most important by the G20s. These are as follows: (a) higher capital requirements, lower leverage, and better risk management and corporate governance; (b) ending the too-big-to-fail ${ }^{6}$ status; (c) increasing the safety of derivative markets; and (d) transforming the shadow banking system (FSB 2015).

Besides coordinating the activities of the international standard-setting bodies, the FSB issued several recommendations: guidance for assessing the systemic importance of financial institutions, guidance for decreasing the reliance on credit rating agencies, a policy framework for strengthening oversight, regulation of shadow banking, etc. ${ }^{7}$

Despite its manifold mandates, the FSB did not become an institution playing a defining role in the area of analysing, coordinating, implementing, and applying macroprudential policies in the first period of its existence (Hellenier 2010). However, the numerous documents related to the situation and degree of implementation of financial reforms published on its website support the transparency of international processes and of national macroprudential regulations.

6 The meaning of the too-big-to-fail status and the importance of its termination will be covered in the presentation of the macroprudential toolset (Section 3.2).

Guidelines about the consistent interpretation and application of the international standards are available on the FSB website: http://www.fsb.org/publications/policy-documents/ 
Following the collapse of Lehmann Brothers, not only the G20s, but also the EU had to urgently react to the challenges of the GFC. In October 2008, the European Commission (EC) requested the high-level expert committee led by Jacques de Larosière to draw the lessons learnt from the crisis for the financial regulation and supervision. The result of their work, the De Larosière Report, was published in March 2009. The main conclusion of the report was that there is an urgent need to establish a macroprudential financial supervision in Europe, and it made a recommendation to set up a European Systemic Risk Council (ESRB). As part of the European System of Financial Supervision, the ESRB, founded in November 2010, is the institution responsible for the macroprudential oversight of the Union's financial system. Besides collecting and analysing data to identify and rank systemic risks, the ESRB issues warnings and recommendations for corrective measures, and it monitors whether they are implemented.

Besides the ESRB, further institutions of macroprudential supervision in the $\mathrm{EU}$ are the designated national authorities (see footnote 5); to a lesser extent, the competent national supervisory authorities, mostly in the area of operative aspects, and the Single Supervisory Mechanism (SSM) within the European Central Bank (ECB) with special mandates. The designated authority responsible for establishing and implementing the macroprudential policy of a given country is defined individually by each country, in accordance with the ESRB recommendation no. 2011/3. According to the survey of the Advisory Scientific Committee operating next to the ESRB (ESRB 2014b), covering the 28 EU member states plus the European Banking Union, the institutional depositaries of the macroprudential mandate for financial stability, i.e. the designated authorities, are in most cases the central banks, both in the euro zone and outside of it (a total of 19 countries plus the Banking Union belong to this group). Denmark is the single country where the designated authority is the Ministry of Finance. The financial supervisory authorities play this role in five countries in the euro zone (Austria, Germany, Finland, Latvia, and Luxembourg) and in Sweden; in Romania, the central bank is responsible for macroprudence with regard to banks and the financial supervisory authority with regard to investment companies. France and Poland designated not an institution, but an inter-institutional committee for this purpose. The EU bank regulation ties the implementation of the macroprudential measures of designated authorities and competent supervisory authorities to the prior notification of the ESRB and, in some cases, to the approval of the EC with prior consultation of the ESRB. The ESRB publishes the received notifications and a clear summary of national macroprudential measures in a table format on its website, which greatly contributes to their transparency.

As the vicious circle of sovereign and bank insolvency became obvious with the spread of GFC in the EU and the burden of bailing out individual countries 
Table 3. Macroprudential mandates in EU

\begin{tabular}{l|l|l}
\hline Institution & \multicolumn{1}{|c}{ Mandate } & \multicolumn{1}{c}{ Scope } \\
\hline ESRB & $\begin{array}{l}\text { EU wide mandate based on regulation } \\
1092 / 2010 \text { EU. }\end{array}$ & All EU member states \\
\hline $\begin{array}{l}\text { Designated national } \\
\text { authorities }\end{array}$ & $\begin{array}{l}\text { National mandates based on CRR and } \\
\text { CRD } \text { and all the other macroprudential } \\
\text { mandates, not regulated on the EU } \\
\text { level. }\end{array}$ & All EU member states \\
\hline $\begin{array}{l}\text { Competent national } \\
\text { supervisory authorities }\end{array}$ & $\begin{array}{l}\text { National mandates based on CRR and } \\
\text { CRD. }\end{array}$ & All EU member states \\
\hline $\begin{array}{l}\text { ECB's Single Supervisory } \\
\text { Mechanism (the SSM) }\end{array}$ & $\begin{array}{l}\text { The right to approve all the } \\
\text { macroprudential tools of national } \\
\text { authorities. In addition, the ECB has } \\
\text { the right to determine higher capital } \\
\text { buffers and stringent macroprudential } \\
\text { measures instead of the ones suggested } \\
\text { by national authorities. }\end{array}$ & $\begin{array}{l}\text { Banking Union member } \\
\text { states }\end{array}$ \\
\hline
\end{tabular}

and their banking systems shifted to the European level, the recognition that responsibility on a European level can be taken only for risks controlled on the level of a Union has become stronger. This led to the creation of the European Banking Union, and within that, as a first step, the Single Supervisory Mechanism (SSM). Thus, the Banking Union is an institution that has been established with a macroprudential perspective, although the SSM has an essentially microprudential mandate (Mérö - Piroska 2013). However, the microprudential tasks of the SSM are complemented with several macroprudential mandates. The distribution of macroprudential mandates within the EU is presented in Table 3.

\subsection{Tools of macroprudential bank regulation}

As Crockett emphasised already in 2000, the difference between macro- and microprudential regulatory tools is not a difference in the tools themselves, but rather the perspective applied in the calibration of the same tool. The macroprudential regulatory tools include all regulatory provisions that decrease the build-up of macroprudential risks either in their cross-sectional or their time dimension, and/ or the tools that increase the banks' macroprudential shock-absorbing capacity. These two possible approaches (i.e. decrease the risk or increase the resilience) also highlight that the applied definition of macroprudential perspective is not

8 CRR: Regulation (EU) No 575/2013; CRD: Directive 2013/36/EU. Based on Basel III, the Regulation and the Directive together are the post-crisis bank regulatory framework in the EU. 
completely clear yet, and this may obviously affect the calibration of the applied tools (Borio 2014).

In 2010, the IMF conducted a survey covering 49 countries and the ECB, assessing what macroprudential tools individual countries apply in their practice (IMF 2011). Based on the survey and a few country case studies, Lim et al. (2011) identified 10 widely used regulatory tools. These are the following:

(a) four lending-related tools (maximum Loan-to-Value ratio for mortgage loans; maximum Debt-to-Income ratio for maximising households' debt repayment burden; limits related to lending in foreign currencies; and caps on lending or on the increase of lending);

(b) three liquidity-related tools (FX open position limits; rules related to maturity mismatch; and liquidity reserve/buffer requirements); and

(c) three capital-related tools (anticyclical/time variant capital requirement; dynamic/time variant provisioning; and restrictions on dividend payments).

The survey revealed that some countries (first of all emerging market economies, e.g. China, India, Croatia and Serbia) introduced macroprudential regulatory tools already before the GFC. After the outbreak of the GFC, one or more macroprudential rules had appeared in the practices of almost all countries, much before the elaboration and acceptance of the related internationally harmonised measures.

In the following, we shall review the tools of macroprudential bank regulation, grouped by the cross-sectional and time dimensions. We take into account only the macroprudential rules that are defined in Basel III and in the almost completely identical EU rules, the CRR and the CRD, in force since January 1, 2014. ${ }^{9}$

The objective of the macroprudential regulation in the cross-sectional dimension is the termination of the "too-big-to-fail" (TBTF) status, in accordance with the previously outlined preference of the FSB, and the avoidal of the simultaneous and concentrated build-up of identical risks in the banking system, which become endogenous this way (alternative definition: increasing the shock-absorbing capacity of banks originating from these risks).

The TBTF status refers to the authorities' practice that - in case of a problem they bail out the largest banks, with the objective to avoid the loss of trust in the banking system and serious disturbances in the functioning of the economy. The TBTF status incents the banks to higher risk-taking that creates moral hazard and destroys incentives for prudent banking. During the GFC, the bail-out packages provided to banks with TBTF status required huge amounts of money from the

The review of the macroprudential rules of the EU by instruments can be found in the socalled Flagship Report (ESRB 2014a) as well. 
taxpayers. This indicated that these banks had grown so large before the crisis ${ }^{10}$ that in case of their bankruptcy, they would require help that exceeds the bearing capacity of their home countries, i.e. they have become practically impossible to save. The requirement to abolish the TBTF status was formulated for this reason. The regulation distinguishes two groups of banks with a special systemic importance: banks representing systemic risk at the level of the global financial system and banks carrying systemic risks at the national level. The regulation prescribes additional capital requirements for both types of institutions in order to decrease their probability of default and the loss given their possible default. The methodology for determining globally significant banks is legally consistent on the EU level and the definition of additional requirements based on this is mandatory; at the same time, it is optional for the designated national authorities concerning institutions that are systemically important on the domestic market. ${ }^{11}$

In the current system, the regulation has three tools for handling identical risks occurring simultaneously. (1) The regulation calls for meeting two new liquidity ratios. (2) The possibility to prescribe a so-called systemic risk capital buffer. This happens when the designated national authority considers that excessive risks are building up in the financial system as a whole, or in one or more subgroups of it. The additional capital requirement is valid only for those institutions in whose case simultaneously building up risks have been identified. (3) The additional capital requirement within the framework of the Supervisory Review and Evaluation Process (SREP) for institutions where excess risks of identical nature are building up in a given period. Besides these three tools serving for managing the cross-sectional risks, the Basel Committee developed one additional tool, to be implemented in the future, that is not yet present in the EU regulation. This is the capital requirement for potential trading losses of banks (i.e. for market risk). It was necessary because although the models used currently measured the potential losses properly in calm periods, they were unable to cope with the massive price falls unfolding in periods of market collapse that resulted in a downward price spiral, i.e. with endogenous risks. The planned new regulation means a complete turn of perspective in the sense that the models to be used are building on the presumption of market turbulences rather than assuming calm markets ${ }^{12}$.

10 The balance sheet total of the largest EU banks exceeded or came near to the GDP of their home Member State. For example, the largest EU bank in 2011 was Deutsche Bank, with a balance sheet total representing $84.8 \%$ of the German GDP, the second was HSBC, with a balance sheet total corresponding to $119.8 \%$ of Great Britain's GDP (Liikanen 2012).

11 Mérő (2013) gives an overview on the banks' motivations for achieving the TBTF status and on the rationale for different regulatory ideas and tools.

12 The new regulatory model is the "expected shortfall", that measures the average market loss that exceeds the given confidence level (BCBS 2016). 
Multiple regulatory tools have been incorporated into the Basel and the European rules as well to decrease the time dimension of macroprudential risks, i.e. the procyclical behaviour of banks too. On the one hand, these are capital rules with the objective that the banks should accumulate an appropriate capital buffer, exceeding the regulatory minimum in the upward course of the cycle. The decrease of the buffer during the downward course of the cycle ensures that the bank will have the regulatory minimum capital even in bad times. This category includes the capital conservation buffer that is equally valid for all banks and prescribes the creation of additional capital in a way that no payment of dividends or bonuses can be performed from the bank's profit until the buffer requirement has not been met. In a recession, when the bank has no profit, this limitation is obviously not effective. On the other hand, this category includes the provision to create countercyclical capital buffer. The banks have to create it only in case the designated national authorities require it because they consider that an excessive credit growth unfolded in the given country. The additional capital requirement prescribed in such periods can reduce the credit growth itself, while the capital buffer can help cover the risks when the lending conditions become unfavourable. The limitation of the banks'leverage (i.e. the unweighted ratio of capital and balance sheet total) also belongs to this category. ${ }^{13}$ In the case of residential mortgage and consumer loans, the national regulatory authorities have further anticyclical tools. There is no mandatory Basel or EU provision for these tools, but the national authorities can apply them in their own competence. These include the loan-to-value (LTV) limits for mortgage loans and the payment-to-income (PTI)type requirements related to the income coverage of both the mortgage and the consumer loans' instalment. Table 4 gives an overview of the macroprudential regulatory tools in cross sectional and time dimension.

Besides the tools listed above, the stress testing exercises both by the individual banks and by the designated and supervisory authorities can promote the macroprudential perspective too. Stress tests assume unfavourable economic scenarios to be able to prepare for them. Depending on the scenarios applied, the perspective of stress tests can be either microprudential or macroprudential. The macroprudential view for stress testing also have been strengthened after the GFC. In the EU, the European Banking Authority regularly performs EU-wide stress tests with the aim of identifying risks and vulnerabilities in a microprudential perspective. However, since the GFC, the designated national authorities (mainly the central banks) regularly conduct stress test with a macroprudential perspective as well.

13 For the procyclical nature of leverage, see Adrian - Shin (2010). 
Table 4. Macroprudential regulatory tools in the European Union

\begin{tabular}{l|l|l}
\hline Dimension of risk & \multicolumn{1}{|c}{ Macroprudential regulatory tool } & \multicolumn{1}{c}{ Aim of the regulation } \\
\hline & $\begin{array}{l}\text { Capital buffers for globally and } \\
\text { domestically systemically importan } \\
\text { banks }\end{array}$ & $\begin{array}{l}\text { Building up excess capital buffer } \\
\text { for the systemically important banks } \\
\text { and for the macroprudential risks. }\end{array}$ \\
\cline { 2 - 3 } Cystemic risk buffer & $\begin{array}{l}\text { Decrease the dependence on } \\
\text { financial markets both for short } \\
\text { and long run in order to ensure } \\
\text { the liquidity. }\end{array}$ \\
\cline { 2 - 3 } Cross sectional & $\begin{array}{l}\text { Obligatory liquidity ratios } \\
\text { to ensure capital coverage for given } \\
\text { types of risks for given groups of } \\
\text { banks. }\end{array}$ \\
\cline { 2 - 3 } Time & $\begin{array}{l}\text { SREP capital requirement above } \\
\text { the minimum (mixed micro- and } \\
\text { macroprudential aim) }\end{array}$ & $\begin{array}{l}\text { Using market risk models that could } \\
\text { incorporate the endogenous risks of } \\
\text { markets. }\end{array}$ \\
\cline { 2 - 3 } & $\begin{array}{l}\text { Planned new perspective for market } \\
\text { risk capital requirement }\end{array}$ & $\begin{array}{l}\text { To accumulate excess capital in } \\
\text { periods of credit growth } \\
\text { and profitable banking. }\end{array}$ \\
\hline & Countercyclical capital buffer & $\begin{array}{l}\text { To limit excessive leverage in } \\
\text { periods of boom. }\end{array}$ \\
\cline { 2 - 3 } Capital conservation buffer & $\begin{array}{l}\text { To limit excessive household credit } \\
\text { growth and indebtedness. }\end{array}$ \\
\cline { 2 - 3 } & Limiting leverage & $\begin{array}{l}\text { LTV and PTI limits for retail } \\
\text { lending }\end{array}$ \\
\cline { 2 - 3 } &
\end{tabular}

\section{CONCLUSIONS: ARE MACROPRUDENTIAL REGULATION AND SUPERVISION CAPABLE OF STABILISING THE BANKING SYSTEM?}

The GFC has brought a radical turn in bank regulation: the previous, solely microprudential perspective has been replaced by the general spread of the macroprudential perspective. The authorities responsible for financial regulation and the markets now strongly believe that a macroprudential perspective and regulation will be able to protect the financial stability in the future. They also believe that if the system of institutions and rules created for this purpose works well, crises of a depth similar to that of the GFC can be avoided in the future.

Since the recurring cyclical crises have formed a part of the economic history for centuries and the endogenous risks of the financial markets have also found various newer forms of appearance as a result of financial innovation and possibilities of regulatory arbitrage, we have to raise the question of whether the macroprudential perspective and regulatory system that is currently in place are really able to prevent large financial crises?

Borio (2014) draws the attention to the fact that no matter how important and good tool the macroprudential regulation is, we should not have too high expectations towards it. As we also pointed out earlier, even the objective of the 
macroprudential regulation can be formulated in two ways: it can either be directed towards decreasing the risk, or towards increasing the macroprudential shock-absorbing capacity of banks. For example, an objective with regard to the time dimension of macroprudential risks can be to increase the banks' resistance to cyclical risks, or to limit the cyclical upswings. Borio's opinion is that a macroprudential regulation is more likely to achieve the former rather than the latter. The same way, he does not think it is a realistic expectation that macroprudential regulation should support the increase of lending in the downward course of the cycle - only the mitigation of the excessive scaling-back of lending can be regarded as a much more realistic goal.

Admati (2016) goes much farther in formulating the doubts. According to her, the Basel III capital regulation system is nothing else but a missed opportunity with regard to regulations aimed at establishing a stable banking system since the capital level of the banking system remains critically low. In her opinion, the fact that banks can operate with a high leverage has not changed after the crisis since banking continues to be the industry with the highest leverage with its limit of three or five percent. This continues to stimulate risk-taking with other people's money. In her opinion, the high leverage is a result of the bankers' high negotiating power since this way, the positive results of risks taken by the bank continue to be theirs, and they only share the negative results with the bank's creditors.

The Vice-Chair of the Advisory Scientific Committee of the ESRB, Hellwig (2014) also emphasises the insufficiency of the leverage limits. He points out that if, for example, a bank's capital is $3 \%$ of its balance sheet total, a one percent loss of the assets wipes out one-third of its capital. Therefore, it should decrease its asset portfolio by roughly a third. If its capital were $20 \%$ of the balance sheet total, it would have to reduce its assets by only five percent because of the same shock. That is, the banking system would be safe only with a much lower leverage.

The above standpoints clearly illustrate that the clarification of the macroprudential regulation's framework and the assessment of its efficiency are yet to come. Nobody knows whether the set targets can be achieved with their help or not, moreover, in some cases, the set targets are somewhat ambiguous. Neither do we know whether the new rules are properly calibrated; what possibilities for regulatory arbitrage (still unknown today) they create; will the interaction between macroprudential and monetary policy create synergy or contradiction; and what risks can build up in the future if they are used. The competition from unregulated shadow banking institutions makes the last point especially emphatic. Even though we do not have proper answers to these questions as yet, we agree with those who express strong doubts as to whether macroprudenial regulation, in its present form, indeed creates a Brave New World. 


\section{REFERENCES}

Admati, A. R. (2016): The Missed Opportunity and Challenge of Capital Regulation. National Institute Economic Review, No. 235: R4-14. February.

Adrian, T. - Shin, H. S. (2009): Liquidity and Leverage. Federal Reserve Bank of New York Staff Report, December.

Allen, F. - Gale, D. (2000): Financial Contagion. The Journal of Political Economy, 108(1): 1-33.

Altman, E. I. - Saunders, A. (2001) : An Analysis and Critique of the BIS Proposal on Capital Adequacy and Ratings. Journal of Banking \& Finance, 25(1): 25-46.

Baker, A. (2013): The New Political Economy of the Macroprudential Ideational Shift. New Political Economy, 18(1): 112-139.

Balatoni, A. (2015): A Simple Fiscal Rule for Hungary. Acta Oeconomica, 65(1): 151-161.

Basel Committee of Banking Supervision (BCBS (2016): Standards. Minimum Capital Requirements for Market Risk. Bank for International Settlements, January.

Bank for International Settlements (BIS) (2001): Marrying the Macro- and Microprudential Dimensions of Financial Stability. BIS Papers, No.1. March.

Bank for International Settlements (BIS) (2008): Addressing Financial System Procyclicality: A Possible Framework. 1 September, Note for the FSF Working Group on Market and Institutional Resilience.

Bank of England (1996): Financial Stability Review, Autumn. Issue one.

Borio, C. (2003): Towards a Macroprudential Framework for Financial Supervision and Regulation? BIS Working Paper, No.128.

Borio, C. (2011): Implementing a Macroprudential Framework: Blending Boldness and Realism, Capitalism and Society, 6(1): Article 1.

Borio, C. (2014): Macroprudential Frameworks: (Too) Great Expectations? In: Schoenmaker, D. (ed.): Macroprudentialism. A VoxEU.org eBook, pp. 29-45.

Borio, C. - Furfine, C. - Lowe, P. (2001): Procyclicality of the Financial System and Financial Stability: Issues and Policy Options. BIS Papers, No.1, pp. 1-57.

Caprio, G. - Klingebiel, D. (1996): Bank Insolvencies: Cross-Country Experience. World Bank Policy Research Working Paper, No. 1620.

Clement, P. (2010): The Term "Macroprudential": Origins and Evolution. BIS Quarterly Review, March, pp. 59-67.

Crockett, A. D. (2000): Marrying the Micro-, and Macro-Prudential Dimensions of Financial Stability. Remarks before the Eleventh International Conference of Banking Supervisors, held in Basel, 20-21 September. BIS Review, 76/2000.

Damodaran, K. - Yejin, C. L. (2014): Macroprudential Policy Framework. A Practice Guide. The World Bank Studies.

Danielsson, J. - Shin, H. S. (2003): Endogenous Risk. In: Field, P. (ed.): Modern Risk Management: A History. Risk Books, pp. 297-313.

Danielsson, J. - Embrechts, P. - Goodhart, C. - Keating, C. - Muennich, F. - Renault, O. - Shin, H. S. (2001): An Academic Response to Basel II. LSE Financial Markets Group Special Paper, No. 130, May.

Dunbar, N. (2000): Inventing Money: The Story of Long-Term Capital Management and the Legends behind It. John Wiley \& Sons Ltd.

European Systemic Risk Board (ESRB) (2012): Recommendation of the ESRB of 22 December 2011 on the Macro-Prudential Mandate of National Authorities. Official Journal of the European Union, 14. February.

European Systemic Risk Board (ESRB) (2014a): Flagship Report on Macro-Prudential Policy in the Banking Sector. Report by the ESRB Instrument Working Group. March. 
European Systemic Risk Board (ESRB) (2014b): Allocating Macro-Prudential Powers. Reports of the Advisory Scientific Committee, No. 5, November.

Financial Stability Board (2015): Implementation and Effects of the G20 Financial Regulatory Reforms. Report of the Financial Stability Board to G20 Leaders. November.

Fisher, I. (1933): The Debt-Deflation Theory of Great Depression. Econometrica, 4: 337-357.

Galati, G. - Moessner, R. (2011): Macroprudential Policy - A Literature Review. BIS Working Papers, No 337.

Helleiner, E. (2010): What Role for the New Financial Stability Board? The Politics of International Standards after the Crisis. Global Policy, 1(3): 282-290.

Hellwig, M. (2014): Systemic Risk and Macro-Prudential Policy. In: Houlben, A. - Niljskens, R. - Teunissen, M. (eds): Putting Macroprudential Policy to Work. De Nederlandsche Bank, Occasional Studies, 12(7): 78-93.

IMF (2000): Macroprudential Indicators of Financial System Soundness. Occasional Paper, No. 192.

IMF (2002): Financial Soundness Indicators: Analytical Aspects and Country Practices. Occasional Paper, No. 212.

IMF (2011): Macroprudential Policy: An Organizing Framework. Background Paper, prepared by Monetary and Capital Market Department, March 14.

Kálmán, J. (2015): A makroprudenciális politika fogalmi kerete és helye a gazdaságpolitika rendszerében (Conceptual framework of the macroprudential policy in the framework of economic policy). Jog-Állam-Politika, VII(2): 27-44.

Kindleberger, Ch. P. (1993): A Financial History of Western Europe. 2nd edition, Oxford University Press.

Kindleberger, Ch. P. (2001): Manias, Panics, and Crashes. A History of Financial Crises. 4th edition, Palgrave Macmillan.

de Larosière, J. (2009): The High Level Working Group on Financial Supervision in the EU. Report, 25. February.

Liikanen, E. (2012): High-Level Expert Group on Reforming the Structure of EU Banking Sector. Final Report. Brussels, October.

Lim, C. - Columba, F. - Kongsamut, P. - Otani, A. - Saiyid, M. - Wezel, T. - Wu, X. (2011): Macroprudential Policy: What Instruments and How to Use Them? Lessons from Country Experiences. IMF Working Paper, WP/11/238.

Lindgren, C. J. - Garcia, G. - Saal, M. I. (1996): Bank Soundness and Macroeconomic Policy. IMF.

Maes, I. (2010): Alexandre Lamfalussy and the Origins of the BIS Macro-Prudential Approach to Financial Stability. PSL Quarterly Review, 63(254): 265-292.

Mérő, K. (2013): Egy paradigma születése és bukása. A „túl nagy a csődhöz” elv értelmezésének és alkalmazásának változásai (Born and fall of a paradigm. Changes in interpretation and implementation of too-big-to-fail principle). In: Valentiny, P. - Kiss, F. L. - Nagy, Cs. I. (eds): Verseny és Szabályozás 2012 (Competition and Regulation 2012). Budapest: MTA KRTK Közgazdaságtudományi Intézet, pp. 32-57.

Mérő, K. - Piroska, D. (2013): A makroprudenciális bankszabályozás és -felügyelés keretrendszerének kialakulása. Egy paradigmaváltás elemzése (The emergence of the macroprudential banking regulation framework. Understanding a paradigm shift). Hitelintézeti Szemle, 12(4): 306-325.

Minsky, H. P. (1986): Stabilizing an Unstable Economy: A Twentieth Century Fund Report. Yale University Press.

Rochet, J. C. - Tirole, J. (1996): Interbank Lending and Systemic Risk. Journal of Money, Credit and Banking, 28(4): 733-762.

Working Group on Strengthening Financial Systems (1988): Report of the Working Group. October. 